\title{
Nilai Transaksi E-Money di Indonesia dengan Menggunakan Metode Markov Switching Model
}

\author{
Maratus Zahro ${ }^{1}$, Rika Rahayu ${ }^{2 *}$ \\ ${ }^{12}$ Sekolah Tinggi Ilmu Ekonomi Indonesia (STIESIA) Surabaya \\ maratuszahro@stiesia.ac.id, rikarahayu@stiesia.ac.id
}

*Penulis Korespondensi

Diajukan : 22 Maret 2021

Disetujui : : 19 April 2021

Dipublikasi : 26 Agustus 2021

\begin{abstract}
The purpose of the research is to examine and analyze the interest rates, inflation rates, stock returns, and holiday conditions on the values of e-money transactions based on two conditions, before and after the issuance of Bank Indonesia regulations. The research data used in this study is the monthly statistical data of the Bank Indonesia payment system for the period 2008-2018. While the research was quantitative using the Markov Regime Switching Model and hypothesis testing using time series regression. The research results showed that there was a significant effect between the inflation rate and the value of e-money transactions. In addition, there was an insignificant effect on interest rates, stock returns, and holiday conditions on the value of e-money transactions. This research contributes to the development of economic research by predicting the value of e-money transactions and predicting the value of e-money transactions and predicting the turning point of e-money transactions value based on two conditions, before and after the issuance of Bank Indonesia regulations and can be used as input to the government regarding the regulations that issued by Bank of Indonesia, regulations regarding increased the value of e-money transactions.
\end{abstract}

Keywords: interest rate, inflation rate, stock return, value of e-money transaction

\section{PENDAHULUAN}

Fenomena e-money telah menjadi perhatian masyarakat Indonesia saat ini. Dalam penggunaan e-money masyarakat dapat merasakan bahwa dengan hadirnya e-money ini diberikan kemudahan dan kecepatan dalam bertransaksi tanpa membawa uang tunai kembali, tidak perlu menerima uang kembalian dalam bentuk barang seperti permen dan lain sebagainya serta sangat mudah digunakan secara bersamaan untuk transaksi transportasi, makanan dan lain sebagainya.

Pemerintah pada tahun 2017 telah gencar mensosialisasikan transaksi e-money dengan membuat Peraturan Bank Indonesia Nomor 18/17/PBI/2016 tentang Uang Elektronik. Peraturan tersebut bertujuan untuk meningkatkan pemakaian e-money serta mendukung keuangan inklusif. Selain itu muncul pula peraturan pemerintah yang mewajibkan pengguna jalan tol menggunakan $e$ money. Nilai transaksi e-money mengalami peningkatan dari tahun 2017 ke tahun 2018 sebesar 422,77 persen. Menurut Bank Indonesia (2018), kenaikan tersebut disebabkan oleh adanya transaksi elektronik sebagai sarana transportasi, transaksi pada bisnis e-commerce serta bertambahnya sejumlah merchant yang menerima $e$-money.

Hidayati et al. (2006) telah memaparkan mengenai kajian e-money yang memiliki potensi sama untuk dikembangkan di Indonesia sebagai alternatif instrumen pembayaran non-tunai, khususnya untuk pembayaran mikro dan retail sehingga diharapkan dapat mendorong masyarakat Indonesia ke arah less cash society. E-money memang perlu diatur lebih jauh mengenai nilainya, dikarenakan setiap e-money harus memiliki nilai yang sama dalam artian nilai $e$-money tidak boleh lebih kecil atau lebih besar karena dapat berdampak inflasi. Suku bunga merupakan salah satu indikator stabilitas sistem keuangan. Naik turunnya suku bunga juga akan mempengaruhi jumlah uang beredar di masyarakat, dimana salah satu uang yang beredar di masyarakat adalah e-money. 
Return saham juga akan berpengaruh terhadap nilai transaksi e-money, dikarenakan ketika harga saham meningkat maka jumlah uang beredar juga akan meningkat. Bank Indonesia sebagai regulator sistem pembayaran telah melakukan pencatatan bahwa menjelang lebaran meningkat drastis pada nilai transaksi e-money.

Uraian tersebut pun juga sesuai dengan beberapa penelitian terdahulu yang pernah dilakukan oleh Lintangsari et al. (2017) terkait suku bunga dan tingkat inflasi yang memengaruhi nilai transaksi e-money. Abidin (2015) juga menjelaskan bahwa e-money merupakan hasil kebijakan sistem pembayaran di Indonesia yang dapat menekan jumlah uang beredar sehingga tingkat inflasi dapat dikontrol oleh Bank Indonesia. Tayibnapis et al. (2018) menjelaskan bahwa e-money dapat menumbuhkan investasi dalam bidang teknologi keuangan salah satunya adalah pada saham atau lebih dikenal dengan equity crowfunding. Begitupun pada kondisi hari raya, Bank Indonesia melihat bahwa adanya kondisi hari raya data nilai transaksi e-money meningkat.

Penelitian ini ingin melihat paradigma adanya pengaruh suku bunga, tingkat inflasi, return saham, IHSG, dan kondisi hari raya terhadap nilai transaksi e-money sebelum dan sesudah diterbitkannya Peraturan Bank Indonesia No. 18/17/PBI/2016 tentang Uang Elektronik.

Penelitian ini diharapkan dapat memberikan manfaat yaitu (1) Dari segi empiris, penelitian ini memberikan kontribusi untuk melakukan pengembangan penelitian akuntansi dan ekonomi dengan memprediksi nilai transaksi e-money dan memprediksi turning point nilai transaksi e-money berdasarkan dua kondisi (sebelum dan sesudah diterbitkannya Peraturan Bank Indonesia) menggunakan metode markov switching model dan (2) Hasil penelitian dapat digunakan sebagai masukan kepada pemerintah terkait peraturan yang telah dikeluarkan oleh Bank Indonesia yakni peraturan mengenai peningkatan e-money.

\section{Nilai Transaksi E-money}

\section{STUDI LITERATUR}

E-money merupakan alat pembayaran yang memenuhi unsur diterbitkan atas dasar nilai uang yang disetor terlebih dahulu kepada penerbit, nilai uang disimpan secara elektronik dalam suatu media seperti server atau chip dan nilai uang elektronik yang dikelola oleh penerbit bukan merupakan simpanan sebagaimana dimaksud dalam undang-undang yang mengatur mengenai perbankan.

Untoro et al. (2014) melakukan kajian penggunaan instrumen sistem pembayaran sebagai leading indicator makroekonomi dengan menggunakan metode markov switching model. Dalam kajian ini menggunakan dua fase yakni fase resesi dan fase ekspansi, dimana bisa menangkap dengan baik di masa krisis maupun masa ekspansi. Dalam kajian ini menggunakan variabel sistem pembayaran yang dapat digunakan sebagai indikasi awal pergerakan ekonomi di Indonesia seperti transaksi RTGS, volume kliring dan volume ATM atau debit dimana ketiga variabel sistem pembayaran tersebut merupakan nilai transaksi e-money.

Azali (2016) melakukan penelitian pada instrumen pembayaran non-cash di Indonesia, dimana mayoritas penduduk Indonesia menggunakan digital cash atau e-money dibandingkan menggunakan card payment dan internet banking. Robiin et al. (2017) melakukan penelitian untuk memberikan solusi baru pada pembayaran secara instan di Indonesia dengan melakukan proses interview. Hasil dari penelitian tersebut menjelaskan bahwa kondisi infrastruktur internet di Indonesia masih belum stabil sehingga menjadi penyebab permasalahan terhadap sistem pembayaran secara instan, sehingga hal tersebut berpengaruh terhadap nilai transaksi $e$-money.

\section{Suku Bunga}

Suku bunga merupakan indikator moneter yang mempunyai dampak dalam beberapa kegiatan ekonomi, dimana akan mempengaruhi keputusan dalam berinvestasi yang pada akhirnya mempengaruhi pertumbuhan ekonomi dan akan mempengaruhi nilai uang beredar di masyarakat.

\section{Tingkat Inflasi}

Tingkat inflasi merupakan kenaikan harga secara umum dan terus menerus dalam jangka waktu tertentu. Indikator yang digunakan dalam mengukur tingkat inflasi adalah Indeks Harga Konsumen (IHK). 


\section{Return Saham}

Return saham merupakan keuntungan yang diperoleh dari pemegang saham sebagai hasil dari investasinya. Dalam artian, return merupakan tingkat pengembalian saham atau investasi yang dilakukan.

\section{Indeks Harga Saham Gabungan (IHSG)}

IHSG merupakan indeks gabungan dari seluruh jenis saham yang tercatat di bursa efek. Perhitungan indeks merepresentasikan pergerakan harga saham di pasar atau bursa yang terjadi melalui sistem perdagangan lelang.

\section{Kondisi Hari Raya}

Kondisi hari raya merupakan fenomena unik yang terjadi dinegara Indonesia yakni mudik. Hal tersebut merupakan kondisi yang berkaitan dengan para masyarakat Indonesia yang banyak menggunakan e-money untuk pembayaran transportasi, makan dan lain sebagainya.

\section{Pengembangan Hipotesis}

Pengaruh Suku Bunga terhadap Nilai Transaksi E-Money

Lintangsari et al. (2017) melakukan penelitian pada suku bunga terhadap instrumen pembayaran non tunai, dimana untuk transaksi e-money berpengaruh negatif dan signifikan secara statistik, transaksi kartu debit tidak berpengaruh signifikan dan transaksi kartu kredit berpengaruh positif dan signifikan secara statistik. Igamo dan Falianty (2018) melakukan penelitian pada suku bunga terhadap e-money yang berpengaruh signifikan secara statistik.

\section{Pengaruh Tingkat Inflasi terhadap Nilai Transaksi E-Money}

Lintangsari et al. (2017) juga melakukan penelitian pada inflasi terhadap instrumen pembayaran non tunai dengan hasil penelitiannya menunjukkan bahwa transaksi e-money, transaksi kartu debit, dan transaksi kartu kredit tidak berpengaruh signifikan terhadap inflasi. Igamo dan Falianty (2018) melakukan penelitian terkait e-money yang akan mensubstitusi uang tunai di Indonesia dengan menggunakan metode vector error correction model, dimana memberikan hasil penelitian bahwa tingkat inflasi berpengaruh signifikan terhadap e-money.

\section{Pengaruh Return Saham terhadap Nilai Transaksi E-Money}

Berdasarkan Peraturan Bank Indonesia yang dituangkan dalam PBI No.20/6/PBI/2018 tentang uang elektronik menjelaskan bahwa salah satunya adalah adanya komposisi kepemilikan saham penerbit yang mengatur paling kurang 51 persen harus dimiliki oleh domestik untuk meningkatkan ketahanan dan daya saing industri uang elektronik nasional dan kepemilikan tunggal calon pemegang saham uang elektronik untuk peningkatan tata kelola dan menjaga persaingan usaha yang sehat dalam industri uang elektronik.

Tayibnapis et al. (2018) melakukan penelitian bahwa e-money dapat meningkatkan investasi teknologi keuangan salah satunya adalah pada saham atau lebih dikenal dengan equity crowfunding, dimana equity crowfunding adalah implementasi layanan penawaran saham oleh perusahaan untuk menjual saham langsung ke investor melalui sistem elektronik menggunakan jaringan internet.

\section{Pengaruh Kondisi Hari Raya terhadap Nilai Transaksi E-Money}

Secara periodik, kebutuhan jumlah e-money beredar pada kondisi hari raya. Hal tersebut didukung oleh data dari Bank Indonesia (2018) yang menunjukkan bahwa adanya kenaikan dari tahun ke tahun terkait jumlah e-money beredar yakni 90 juta e-money (2017), 167 juta e-money (2018) dan diperkirakan mencapai 197 juta e-money (2019).

\section{METODE}

Jenis penelitian ini termasuk dalam penelitian deskriptif karena bertujuan untuk memperoleh model untuk memprediksi nilai transaksi e-money ke depan dengan menggunakan variabel suku bunga, tingkat inflasi, return saham dan kondisi hari raya serta memprediksi terjadinya suatu turning point nilai transaksi e-money ke depan dengan menggunakan variabel suku bunga, tingkat 
inflasi, return saham dan kondisi hari raya. Data penelitian yang digunakan dalam penelitian ini merupakan data bulanan statistik sistem pembayaran Bank Indonesia selama periode 2009-2018.

\section{Teknik Analisis Data \\ Uji Stasioneritas}

Stasioneritas merupakan salah satu prasyarat penting dalam model ekonometrika untuk data runtut waktu (time series). Data stasioner adalah data yang menunjukkan mean, varians dan autovarians (pada variasi lag) tetap sama pada waktu kapan saja data itu dibentuk atau dipakai, artinya dengan data yang stasioner model time series dapat dikatakan lebih stabil. Apabila data yang digunakan dalam model ada yang tidak stasioner, maka data tersebut dipertimbangkan kembali validitas dan kestabilannya.

\section{Markov Switching Model}

Menurut Gunanjar (2006), peubah-peubah ekonomi makro dalam siklus bisnis seringkali mengalami perubahan kondisi akibat krisis ekonomi. Perubahan ini diasumsikan merupakan proses stokastik yang membangkitkan peubah acak tidak teramati bersifat diskret yang dikenal dengan rantai Markov. Model MSVAR adalah model yang menggabungkan model Vector Autoregressive (VAR) dengan model rantai Markov. Model VAR berfungsi sebagai pembangkitan data sedangkan model rantai Markov sebagai pembangkitan kondisi. Apabila semua parameter VAR berada pada kondisi St pada rantai Markov, maka parameter tersebut bergantung pada kondisi M. Banyaknya regime (kondisi) $\mathrm{M}$ dalam siklus bisnis sering diasumsikan ke dalam dua state yaitu tidak krisis dan krisis. MS(M)-VAR(p) dimodelkan sebagai berikut (Krolzig, 1997).

$$
y \_t=v\left(s \_t\right)+A \_1\left(s \_t\right) y \_(t-1)+\cdots+A \_p\left(s \_t\right) y \_(t-p)+\varepsilon \_t
$$

Dengan $y t$ adalah vektor peubah endogen periode-t, $\boldsymbol{y} t-p$ adalah vektor peubah endogen periode-(t-p), $\boldsymbol{v}$ adalah vektor konstanta, $\boldsymbol{A} p$ adalah matriks parameter $\operatorname{VAR}(\mathrm{p}), \boldsymbol{\varepsilon} \boldsymbol{t} \mid s t \sim M V N(\mathbf{0}$, $\Sigma(s t)), \mathrm{p}$ adalah orde dari model VAR.

\section{Menentukan Threshold}

Perhitungan threshold secara stokastik dapat dilakukan dengan pemodelan Markov switching regression.

\section{Uji Normalitas Data}

Pengujian normalitas data menggunakan uji kolmogorov smirnov. Analisis normalitas data yang menggunakan uji kolmogorov smirnov dilakukan dengan melihat nilai probabilitas signifikansi atau asymp. Sig (2-tailed) memiliki distribusi normal atau tidak. Jika nilai probabilitas signifikasi kurang dari nilai 0.05 , maka data tidak terdistribusi secara normal. Sedangkan jika nilai probabilitas signifikansi lebih dari nilai 0.05 , maka data terdistribusi secara normal.

\section{Uji Autokorelasi}

Hasil uji autokorelasi pada data time series penelitian ini menggunakan pengujian Ljung-Box.

\section{Regresi Time Series}

Regresi time series merupakan fungsi antara satu variabel dependen dengan satu atau lebih variabel independen dimana kedua variabel tersebut bersyarat pada waktu. penelitian ini menggunakan regresi time series untuk menguji pengaruh suku bunga, tingkat inflasi, return saham, IHSG, dan kondisi hari raya terhadap nilai transaksi e-money.

\section{Identifikasi Kestasioneran Data}

\section{HASIL}

\section{Uji Stationeritas dengan Grafik ACF dan PACF}

Persyaratan penting dalam model ekonometrika untuk data time series dengan ketentuan data tersebut bisa digunakan kapan saja dan dinyatakan stabil sehingga tidak diperlukan uji validitas dan 
reliabilitas. Dalam penelitian ini untuk menguji kestasioneran data secara visual dapat dilihat dari plot data secara aktual, dilanjutkan dengan menggunakan pasangan autocorrelation fuction (ACF) dan partial autocorrelation function (PACF). Grafik ACF ini digunakan untuk menentukan kestasioneran data time series yang digunakan dengan melihat lag-lag yang turun secara eksponensial. Grafik PACF digunakaan untuk menentukan kelas data time series.

Dalam grafik gambar 2 dan 3 ini dapat diperlihatkan bahwa signifikansi untuk data tersebut menunjukkan kestabilan. Berdasarkan ACF dan PACF yang terbentuk dapat disimpulkan bahwa data sudah stasioner dalam mean. Dikatakan tidak stasioner mean apabila ACF dan PACF turun pelan dan keluar dari batas signifikasi hingga lag yang panjang. ACF merupakan korelasi anatara nilai-nilai berkala yang sama dengan selisih waktu (time lag). PACF merupakan fungsi untuk mengukur tingkat keeratan saat pengaruh dari time lag dianggap terpisah. Pada grafik ACF memperlihatkan grafik turun secara tajam hal ini menunjukkan data telah stasioner. Model yang digunakan dikatakan telah independen karena tidak ada satu lag pada grafik PACF residual yang keluar dari batas garis. Kedua grafik tersebut menunjukkan pola dying down dalam klasifikasi autokorelasi.

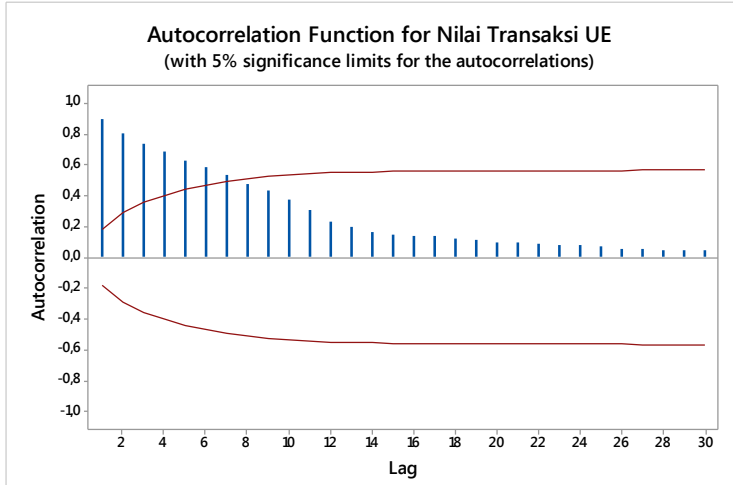

Gambar 1. Grafik ACF

Sumber: Data Sekunder, 2020 (diolah)

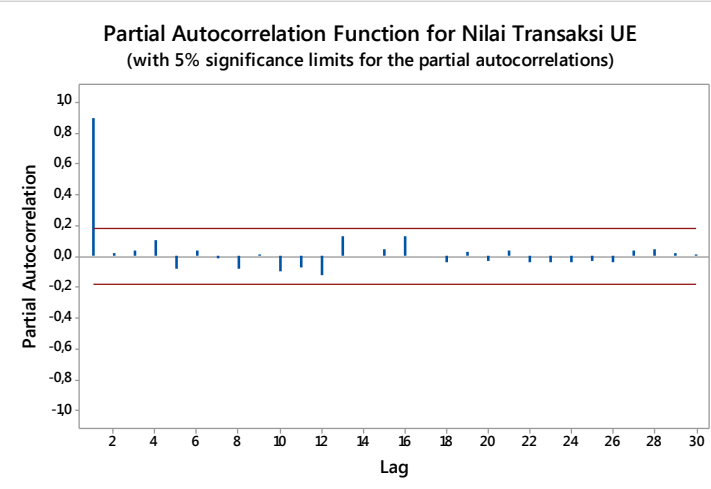

Gambar 2. Grafik PACF

Sumber: Data Sekunder, 2020 (diolah)

\section{Uji Stationeritas dengan Uji Dicky Fuller}

Hasil kestasioneran data yang ditunjukkan dengan grafik ACF dan PACF juga diperkuat dengan hasil uji Dickey Fuller yang menunjukkan bahwa data sudah stasioner dalam mean. Nilai $P$-value dari single mean dan tren menunjukkan angka $<0,05$. Nilai dengan uji Dickey Fuller menunjukkan nilai 0.0010 .

Tabel 1. Dickey-Fuller Unit Root Tests

\begin{tabular}{|l|r|r|r|r|r|r|r|}
\hline Type & \multicolumn{1}{|l|}{ Lags } & \multicolumn{1}{|c|}{ Rho } & Pr $<$ Rho & \multicolumn{1}{c|}{ Tau } & Pr $<$ Tau & F & Pr $<\mathbf{F}$ \\
\hline Zero Mean & 0 & 9.4812 & 0.9999 & 5.52 & 0.9999 & & \\
\hline Single Mean & 0 & 9.6104 & 0.9999 & 4.76 & 0.9999 & 15.11 & 0.0010 \\
\hline Trend & 0 & 8.4963 & 0.9999 & 3.03 & 0.9999 & 11.44 & 0.0010 \\
\hline
\end{tabular}

Sumber: Data Sekunder, 2020 (diolah)

\section{Regresi Time Series}

\section{Uji Normalitas}

Dalam uji normalitas pada data time series di penelitian ini menggunakan pengujian Kolmogorov Smirnov. Berikut hasil dari pengujian Kolmogorov Smirnov.

Tabel 3. Pengujian Kolmogorov Smirnov

\begin{tabular}{|l|l|}
\hline Kolmogorov-Smirnov Z & 0.0730 \\
\hline Asymp. Sig. (2-tailed) & 0.1177 \\
\hline
\end{tabular}

Sumber: Data Sekunder, 2020 (diolah) 
Hasil uji normalitas pada penelitian ini menggunakan uji Kolmogorov-Smirnov terhadap data residual dari persamaan regresi. Pengujian dengan menggunakan Kolmogorov-Smirnov menunjukkan probabilitas (signifikansi) pengujian sebesar 0.1177. Signifikansi probabilitas yang lebih dari 0,05 menunjukkan data telah terdistribusi dengan normal.

\section{Uji Autokorelasi}

Hasil uji autokorelasi pada data time series penelitian ini menggunakan pengujian Ljung-Box. Berikut hasil dari pengujian Ljung-Box.

Tabel 4. Autocorrelation Check of Residuals

\begin{tabular}{|r|r|r|r|}
\hline \multicolumn{1}{|l|}{ To Lag } & \multicolumn{1}{l|}{ Chi-Square } & \multicolumn{1}{l|}{ DF $\mathbf{l}$ ChiSq } \\
\hline 6 & 4.60 & 5 & 0.4666 \\
\hline 12 & 14.06 & 11 & 0.2296 \\
\hline 18 & 19.20 & 17 & 0.3171 \\
\hline 24 & 23.70 & 23 & 0.4208 \\
\hline 30 & 29.86 & 29 & 0.4209 \\
\hline 36 & 34.66 & 35 & 0.4846 \\
\hline 42 & 36.28 & 41 & 0.6802 \\
\hline 48 & 38.45 & 47 & 0.8083 \\
\hline 54 & 44.77 & 53 & 0.7821 \\
\hline 60 & 53.54 & 59 & 0.6762 \\
\hline 66 & 56.11 & 65 & 0.7762 \\
\hline 72 & 57.35 & 71 & 0.8794 \\
\hline 78 & 64.13 & 77 & 0.8524 \\
\hline 90 & 71.11 & 83 & 0.8209 \\
\hline 96 & 71.68 & 89 & 0.9103 \\
\hline 102 & 74.69 & 95 & 0.9388 \\
\hline 108 & 77.59 & 101 & 0.9597 \\
\hline 114 & 79.23 & 107 & 0.9796 \\
\hline 79.69 & 113 & 0.9926 \\
\hline
\end{tabular}

Sumber: Data Sekunder, 2020 (diolah)

Dapat dilihat bahwa nilai $p$-value $>0,05$ sehingga dapat disimpulkan bahwa residual sudah memenuhi kondisi white noise.

\section{Pemodelan Markov Regime Switching}

\section{PEMBAHASAN}

Pada pemodelan Markov Switching digunakan 2 regime karena ingin dilihat dampak sebelum diterbitkan Peraturan Bank Indonesia Nomor 18/17/PBI/2016 dan sesudah diterbitkannya Peraturan Bank Indonesia Nomor 18/17/PBI/2016. Untuk mendukung model markov diperkuat dengan model linier yaitu model autoregresif dengan konsep regime (MSVAR). Untuk orde AR yang digunakan yaitu AR(1), AR(2), dan AR(3). Digunakan orde tersebut karena data pada data yang dinyatakan stasioner membentuk pola tren naik dan tidak ada pola musimam. Jadi peluang terbesar orde AR yang terbentuk dilakaukan melalu tiga tingkatan dari model yaitu AR(1), AR(2), AR(3). Berikut hasil dari pemodelan dengan orde $\operatorname{AR}(1), \operatorname{AR}(2), \operatorname{AR}(3)$.

Berdasarkan ketiga model pada tabel 3 tersebut yang paling sesuai yaitu model $\mathrm{M}(2), \operatorname{AR}(1)$, semua variabel pada model tersebut hampir signifikan semua pada level of significant $5 \%$ yaitu nilai seluruh variabel pada regime 1 yaitu $0.000<0.05$ dan nilai pada regime 2 yaitu $0.049<0.005$ dan hanya ada satu variabel yang signifikan pada level of signifikan $10 \%$ yaitu P11-C dengan nilai $0,070<0,10$ dan P21-C dengan nilai $0.000<010$. Untuk menentukan lag optimal yang paling minimum pada model VAR dilihat dari nilai Akaike Info Criterion (AIC) pada model M(2), AR(1) adalah 26.61. Model M(2), AR(1) memiliki perumusan pada regime 1 dan regime 2 adalah sebagai berikut:

\section{Model Regime 1}

$\mathrm{Yt}=1289954+1,13 \mathrm{Yt}-1$ 
Owner: Riset \& Jurnal Akuntansi

e-ISSN : 2548-9224 |p-ISSN : 2548-7507

Volume 5 Nomor 2, Agustus 2021

DOI : https://doi.org/10.33395/owner.v5i2.392

\section{Model Regime 2}

$\mathrm{Yt}=194909,6+1,13 \mathrm{Yt}-1$

Proses white noise merupakan proses antar variabel random secara berurutan tidak terjadi suatu korelasi dan dan terdistribusi pada model tertentu. Pada model M(2), AR(1) dinyatakan white noise telah terpenuhi.

Tabel 2. Pemodelan Markov Switching

\begin{tabular}{|c|c|c|c|c|c|c|c|}
\hline Model & Variabel & Koefisien & Z-stat & $\begin{array}{l}\text { P- } \\
\text { Value }\end{array}$ & AIC & $\begin{array}{l}\text { Residual } \\
\text { berdistribusi } \\
\text { normal }\end{array}$ & $\begin{array}{l}\text { White } \\
\text { Noise }\end{array}$ \\
\hline \multirow{6}{*}{$\mathrm{M}(2), \mathrm{AR}(1)$} & $\mathrm{C}$ regime 1 & 1289954 & 9,45 & 0,000 & \multirow{6}{*}{26,61} & \multirow{6}{*}{ Tidak } & \multirow{6}{*}{ Terpenuhi } \\
\hline & $\mathrm{C}$ regime 2 & 194909,6 & 1,97 & 0,049 & & & \\
\hline & $\mathrm{AR}(1)$ & 1,13 & 79,29 & 0,000 & & & \\
\hline & $\log ($ Sigma $)$ & 11,76 & 176,8 & 0,000 & & & \\
\hline & P11-C & 1,89 & 1,81 & 0,070 & & & \\
\hline & $\mathrm{P} 21-\mathrm{C}$ & $-4,76$ & $-4,61$ & 0,000 & & & \\
\hline \multirow{7}{*}{$\mathrm{M}(2), \mathrm{AR}(2)$} & C regime 1 & 1336616 & 7,72 & 0,000 & \multirow{7}{*}{26,53} & \multirow{7}{*}{ Tidak } & \multirow{7}{*}{ Tidak } \\
\hline & C regime 2 & 171402,2 & 1,12 & 0,260 & & & \\
\hline & $\mathrm{AR}(1)$ & 1,45 & 15,73 & 0,000 & & & \\
\hline & $\mathrm{AR}(2)$ & $-0,37$ & $-3,5$ & 0,000 & & & \\
\hline & $\log ($ Sigma $)$ & 11,7 & 174,52 & 0,000 & & & \\
\hline & P11-C & 1,89 & 1,8 & 0,070 & & & \\
\hline & $\mathrm{P} 21-\mathrm{C}$ & $-4,77$ & $-4,58$ & 0,000 & & & \\
\hline \multirow{8}{*}{$\mathrm{M}(2), \mathrm{AR}(2)$} & $\mathrm{C}$ regime 1 & -704642 & $-3,52$ & 0,000 & \multirow{8}{*}{26,66} & \multirow{8}{*}{ Tidak } & \multirow{8}{*}{ Tidak } \\
\hline & $\mathrm{C}$ regime 2 & 71465,83 & 0,37 & 0,710 & & & \\
\hline & $\mathrm{AR}(1)$ & 1,15 & 11,97 & 0,000 & & & \\
\hline & $\mathrm{AR}(2)$ & 0,09 & 0,63 & 0,530 & & & \\
\hline & $\mathrm{AR}(3)$ & $-0,18$ & $-1,63$ & 0,100 & & & \\
\hline & $\log ($ Sigma $)$ & 11,73 & 172,61 & 0,000 & & & \\
\hline & P11-C & 0,68 & 0,79 & 0,430 & & & \\
\hline & P21-C & $-4,03$ & $-5,45$ & 0,000 & & & \\
\hline
\end{tabular}

Sumber: Data Sekunder, 2020 (diolah)

\section{Pemodelan Regresi Time Series}

Pemodelan regresi time series untuk data nilai transaksi e-money melibatkan additive outliers dan level shifts untuk mendapatkan model yang memenuhi asumsi residul berdistribusi normal dan white noise. Berikut adalah model yang terbentuk.

Tabel 5. Model Regresi Time Series

\begin{tabular}{|l|r|r|r|r|r|l|}
\hline Parameter & \multicolumn{1}{|l|}{ Estimate } & $\begin{array}{l}\text { Standard } \\
\text { Error }\end{array}$ & \multicolumn{1}{l|}{ t Value } & Approx Pr $>\mathbf{t}$ & Lag & Variable \\
\hline AR1,1 & 1.00000 & 0.04062 & 24.62 & $<.0001$ & 1 & NT \\
\hline NUM1 & 1604.8 & 1599.8 & 1.00 & 0.3193 & 0 & SB \\
\hline NUM2 & 16898.6 & 4009.7 & 4.21 & $<.0001$ & 0 & INFLASI \\
\hline NUM3 & 1061.8 & 4854.5 & 0.22 & 0.8275 & 0 & RS \\
\hline NUM4 & 49598.3 & 31202.2 & 1.59 & 0.1164 & 0 & IHSG \\
\hline NUM5 & 7735.8 & 5378.7 & 1.44 & 0.1548 & 0 & LEB \\
\hline NUM6 & 3247.5 & 2040.5 & 1.59 & 0.1160 & 0 & TREND \\
\hline
\end{tabular}

Keterangan: NT = jumlah nilai transaksi UE, $\mathrm{SB}=$ Suku Bunga, RS = Return Saham, RI = Return IHSG, LEB = variabel dummy lebaran

Sumber: Data Sekunder, 2020 (diolah) 
Dapat dilihat pada output terdapat penambahan input lag AR (1). Lag AR (1) tersebut merupakan lag dari variabel nilai transaksi e-money. Pada output tersebut dapat dilihat hanya variabel inflasi yang berpengaruh terhadap jumlah nilai transaksi $e$-money.

Hasil regresi time series menunjukkan bahwa nilai signifikansi suku bunga adalah 0.3193 yaitu lebih besar dari 0.05 sehingga suku bunga tidak berpengaruh secara signifikan terhadap transaksi e-money. Hasil ini berbeda dengan Lintangsari et al. (2017) yang melakukan penelitian pada suku bunga terhadap instrumen pembayaran non tunai, dimana untuk transaksi e-money berpengaruh negatif dan signifikan secara statistik, sedangkan transaksi kartu debit tidak berpengaruh signifikan dan transaksi kartu kredit berpengaruh positif dan signifikan secara statistik. Igamo dan Falianty $\underline{(2018)}$ melakukan penelitian pada suku bunga terhadap e-money yang berpengaruh signifikan secara statistik.

Hasil regresi time series menunjukkan bahwa nilai signifikansi tingkat inflasi adalah 0.0001 yaitu lebih kecil dari 0.05 sehingga tingkat inflasi berpengaruh secara signifikan terhadap transaksi e-money. Hal ini menunjukkan bahwa salah satu penyumbang inflasi di Indonesia adalah kenaikan transaksi e-money. Igamo dan Falianty (2018) melakukan penelitian terkait e-money yang akan mensubstitusi uang tunai di Indonesia dengan menggunakan metode vector error correction model, dimana memberikan hasil penelitian bahwa tingkat inflasi berpengaruh signifikan terhadap $e$ money.

Hasil regresi time series menunjukkan bahwa nilai signifikansi return saham adalah 0.8275 yaitu lebih besar dari 0.05 sehingga return saham tidak berpengaruh secara signifikan terhadap transaksi e-money. Tayibnapis et al. (2018) melakukan penelitian bahwa e-money dapat meningkatkan investasi teknologi keuangan salah satunya adalah pada saham atau lebih dikenal dengan equity crowfunding, dimana equity crowfunding adalah implementasi layanan penawaran saham oleh perusahaan untuk menjual saham langsung ke investor melalui sistem elektronik menggunakan jaringan internet. Namun hal ini berbeda dengan hasil penelitian yang menunjukkan bahwa return saham tidak berpengaruh secara signifikan terhadap transaksi $e$-money.

Hasil regresi time series menunjukkan bahwa nilai signifikansi IHSG adalah 0.1164 yaitu lebih besar dari 0.05 sehingga IHSG tidak berpengaruh secara signifikan terhadap transaksi $e$-money. Hasil regresi time series menunjukkan bahwa nilai signifikansi kondisi hari raya adalah 0.1548 yaitu lebih besar dari 0.05 sehingga kondisi hari raya tidak berpengaruh secara signifikan terhadap transaksi e-money. Hal ini menunjukkan bahwa kebutuhan e-money tidak dipengaruhi oleh kondisi hari raya.

\section{KESIMPULAN}

Dari hasil penelitian menunjukkan bahwa model yang cocok digunakan untuk menguji variabel-variabel seperti suku bunga, tingkat inflasi, returns saham, IHSG, kondisi hari raya dan nilai transaksi e-money dengan menggunakan model markov switching dengan menggabungkan model Vector Autoregressive (VAR) dengan rantai markov. Pada variabel makro ekonomi dengan menggunakan markov switching model, yaitu variabel suku bunga, tingkat inflasi, returns saham, IHSG, kondisi hari raya, yang memiliki pengaruh secara signifikan terhadap transaksi e-money adalah tingkat inflasi. Hal ini menunjukkan bahwa salah satu penyumbang inflasi di Indonesia adalah kenaikan transaksi e-money. Berdasarkan pembahasan dan simpulan di atas, maka saran yang dapat dikemukakan adalah sebagai berikut: (1) penelitian ini hanya berfokus pada variabel ekonomi makro, sehingga untuk peneliti selanjutnya akan lebih baik jika memperluas obyek penelitian; (2) penelitian selanjutnya diharapkan mampu menambah variabel lain yang dapat digunakan sebagai instrumen yang dapat memprediksi kenaikan transaksi e-money; (3) penelitian selanjutnya dapat menggunakan teknik analisis data yang lain sehingga bisa mendapatkan hasil yang lebih valid. Terdapat beberapa keterbatasan dalam penelitian ini yaitu variabel ekonomi makro yang berpengaruh terhadap transaksi e-money hanya tingkat inflasi.

\section{UCAPAN TERIMA KASIH}

Penulis mengucapkan terima kasih kepada Kementerian Riset dan Teknologi/Badan Riset dan Inovasi Nasional Deputi Bidang Penguatan Riset dan Pengembangan yang telah memberikan pendanaan penelitian Tahun Anggaran 2020 beserta Koordinator Kopertis Wilayah VII, serta 
Sekolah Tinggi Ilmu Ekonomi Indonesia (STIESIA) Surabaya dengan kontrak Nomor: 071/SP2H/LT-MONO/LL7/2020.

\section{REFERENSI}

Abidin, M. S. (2015). Dampak Kebijakan E-Money di Indonesia sebagai Alat Sistem Pembayaran Baru. Jurnal Akuntansi UNESA 3(2).

Azali, K. 2016. Cashless in Indonesia: Gelling Mobile E-frictions?. Journal of Southeast Asian Economies (JSEAE) 33(3): 364-386.

Bank Indonesia. (2016). Peraturan Bank Indonesia No. 18/17/PBI/2016 Tentang Uang Elektronik (Electronic Money). Jakarta.

Bank Indonesia. (2018). Uang Elektronik. https://www.bi.go.id/id/statistik/sistempembayaran/uang-elektronik/Contents/Penyelenggara\%20Uang\%20Elektronik.aspx. Diakses tanggal 13 Agustus 2018.

Bry, G. dan Boschan, C. (1971). Cyclical Analysis of Time Series: Selected Procedures and Computer Programs. NBER. New York.

Gunanjar, B. (2006). Penerapan Model ARCH/GARCH dan Model MSAR (Markov-Switching Autoregression) pada Nilai Tukar Rupiah terhadap Dolar Amerika dan IHSG. Skripsi. Fakultas Matematika dan Ilmu Pengetahuan Alam, Institut Pertanian Bogor. Bogor.

Hidayati, S., Nuryanti, I., Firmansyah, A., Fadly, A., dan Darmawan, I. Y. (2006). Operasional EMoney. Kajian Bank Indonesia Edisi Oktober 2016.

Igamo, A. M. dan Falianty, T. A. (2018). The Impact of Electronic Money on The Efficiency of The Payment System And The Substitution of Cash In Indonesia. Sriwijaya International Journal Of Dynamic Economics And Business (SIJDEB) 2(3): 237-254.

Krolzig, H. M. (1997). Markov Switching Vector Autoregressions: Modelling, Statistical Inference and Application to Business Cycle Analysis. Springer. Berlin.

Lintangsari, N. N., Hidayati, N., Purnamasari, Y., Carolina, H., dan Febranto, W. (2017). Analisis Pengaruh Instrumen Pembayaran Non Tunai Terhadap Stabilitas Sistem Keuangan di Indonesia. Jurnal Dinamika Ekonomi Pembangunan 1(1): 47-62.

Robiin, B., Wardana, L. A., dan Suyoto. 2017. New Solutions for Instant Payment Problems in Indonesia. International Journal on Advanced Science Engineering Information Technology $7(4)$.

Tayibnapis, A. Z., Waryuningsih, L. E., dan Gora, R. (2018). The Development of Digital Economy in Indonesia. International Journal of Management and Business Studies 8(3): 14-18.

Untoro, R. W., Priyo, dan Arifin, M. S. (2014). Kajian Penggunaan Instrumen Sistem Pembayaran Sebagai Leading Indicator Makroekonomi. Working Paper Bank Indonesia WP/6/2014. 